Check for updates

Cite this: RSC Adv., 2018, 8, 27181

Received 22nd June 2018

Accepted 26th July 2018

DOI: $10.1039 / \mathrm{c} 8 \mathrm{ra05369c}$

rsc.li/rsc-advances

\section{Comparison of enhancement of anaerobic digestion of waste activated sludge through adding nano-zero valent iron and zero valent iron $\dagger$}

\begin{abstract}
Yayi Wang, (D)* Duanli Wang and Huiying Fang
The feasibility of adding nano-zero valent iron (NZVI: $0.6,1.0,4.0,10.0 \mathrm{~g} \mathrm{~L}^{-1}$ ) to enhance anaerobic digestion of waste activated sludge (WAS) was examined by comparison with ZVI, and the mechanisms of NZVI enhancement of the hydrolysis and methanogenesis processes were elucidated. NZVI could enhance hydrolysis-acidification of WAS by destroying the integrity of microbial cells. Both volatile fatty acids production and the acetic acid portion were greatly improved by NZVI additions, peaking at $4.0 \mathrm{~g}$ $\mathrm{L}^{-1} \mathrm{NZVI}$. In anaerobic digestion, $\mathrm{CH}_{4}$ production was promoted at a $\mathrm{NZVI}$ dosage $\leq 1.0 \mathrm{~g} \mathrm{~L}^{-1}$. The optimum dosage of $\mathrm{NZVI}$ for methanogenesis was $1.0 \mathrm{~g} \mathrm{~L}^{-1}$, and further addition of $\mathrm{NZVI}$ could cause inhibition of methanogenesis because of long-term accumulation of $\mathrm{H}_{2}$. ZVI could also improve hydrolysis-acidification and the $\mathrm{CH}_{4}$ yield, but its efficiency was relatively low compared with $\mathrm{NZVI}$, and it could not induce cell wall rupture. 16S rDNA high-throughput sequencing results showed that NZVI addition at appropriate dosage facilitated increasing the proportion of microorganisms involved in WAS hydrolysis-acidification and methanogenesis.
\end{abstract}

\section{Introduction}

Anaerobic digestion has been widely used for treatment of waste activated sludge (WAS) in wastewater treatment plants (WWTPs) to recover energy resources such as volatile fatty acids (VFAs) and methane $\left(\mathrm{CH}_{4}\right)$. The recovery of energy resources from waste activated sludge can equal $70-80 \%$ of the energy consumption required to run WWTPs if the efficiency of anaerobic digestion is maximized. ${ }^{1}$ Therefore, anaerobic digestion of WAS can be one of the key steps to achieve "carbon neutral" or even "carbon positive" WWTPs. ${ }^{2}$ However, in practical conditions, the sum of energy recovered from WAS anaerobic digestion is only $5-7 \%$ of that theoretically available in the raw wastewater, providing only about $33.3 \%$ of the energy required for wastewater treatment. ${ }^{3}$ It is primarily because $\mathrm{CH}_{4}$ production is limited in that only $40-50 \%$ of the organics in WAS can be converted into biogas. ${ }^{4}$

To improve biochemical methane potential (BMP), various pretreatments have been adopted to accelerate hydrolysis of WAS, including thermal methods like incineration, gasification and pyrolysis, super- and subcritical wet oxidation, and hydrothermal treatment; ${ }^{5}$ chemical methods like free nitrous acid

State Key Laboratory of Pollution Control and Resources Reuse, Shanghai Institute of Pollution Control and Ecological Security, College of Environmental Science and Engineering, Tongji University, Siping Road, Shanghai 200092, P. R. China. E-mail: yayi.wang@tongji.edu.cn

$\dagger$ Electronic supplementary information (ESI) available. See DOI: 10.1039/c8ra05369c
(FNA) pretreatment, ${ }^{6}$ Cd pretreatment, ${ }^{7}$ alkaline pretreatment, ozone pretreatment, and electrocoagulation; ${ }^{8}$ and mechanical methods like ultrasound, ballmills, high pressure homogenization, and mechanical jets. ${ }^{9}$ For example, previous studies showed free nitrous acid (FNA) serving as a pretreatment method for alkaline fermentation could enhance short-chain fatty acid production from WAS as it accelerated disruption of both extracellular polymeric substances and cell envelope. ${ }^{6} \mathrm{Xu}$ et $a .^{7}$ also found that low concentration of Cd enhanced solubilization, hydrolysis and acidogenesis processes of WAS anaerobic fermentation. However, most of these methods have the disadvantage of low cost-efficiency because of high energy consumption and high chemical agent requirements, ${ }^{8}$ which has become a great barrier to achieving "carbon neutral" water treatment. ${ }^{10}$ Therefore, alternative efficient methods are urgently required to enhance anaerobic digestion.

Zero valent iron (ZVI) has been reported to significantly accelerate anaerobic digestion, ${ }^{\mathbf{1 1}, \mathbf{1 2}}$ and its accelerating efficiency is directly proportional to its specific surface area. Thus, nano-zero valent iron (NZVI), a strong reductant $\left(E_{\mathrm{h}}=-0.44 \mathrm{~V}\right)$, can be more effective than ZVI in accelerating anaerobic digestion because the specific surface area of NZVI is much larger than that of ZVI. ${ }^{\mathbf{1 3 4 1 4}}$ Moreover, when compared with ZVI, NZVI can remove a wider range of pollutant species thoroughly and rapidly, which favors the complete degradation of organics and shortens the reaction time.

So far, however, most relevant studies have examined the impact of ZVI on anaerobic digestion; ${ }^{\mathbf{1 1}, \mathbf{1 2 , 1 5}}$ although there have been a few studies on NZVI, there is still a lack of consensus on 
the influence of NZVI on anaerobic digestion of WAS. ${ }^{\mathbf{1 3 , 1 4 , 1 6}}$ For example, Su et al. ${ }^{\mathbf{1 4}}$ found that $0.1 \mathrm{wt} \%$ of NZVI in anaerobic digestion for 17 days improved the production of biogas and methane by $30.4 \%$ and $40.4 \%$ respectively. In contrast, inhibition of methanogens at concentrations of $10 \mathrm{mM} \mathrm{NZVI} \mathrm{and}$ above was observed with a reduction of methane production of $20.0 \% .^{16}$ It seems that the impacts of NZVI on anaerobic digestion are greatly dependent on the NZVI dosage, the sludge characteristics and the microbial structure in the system. Moreover, information is still limited regarding how and why $\mathrm{CH}_{4}$ production is affected by addition of NZVI, but this information is important for understanding the mechanism of the effect(s) of NZVI on anaerobic digestion processes. Therefore, more in-depth and all-round research on the effects of NZVI on anaerobic digestion is required.

In this study, we investigated the effects of different dosages of NZVI on hydrolysis-acidification and the complete anaerobic digestion process of WAS separately and compared them with ZVI addition. Microbial community structure and the relative abundance of hydrolysis-acidification bacteria and methanogenic archaea at different NZVI and ZVI dosages were analyzed by Illumina $16 \mathrm{~S}$ rRNA high-throughput sequencing. The main objectives of this study were: (1) to verify the feasibility of NZVI enhancing anaerobic digestion; (2) to determine the optimal NZVI dosage for enhancing different stages of anaerobic digestion, including hydrolysis, acidification and methanogenesis; and (3) to elucidate the mechanisms of NZVI enhancing anaerobic digestion. The results help to extend our knowledge regarding the effects of NZVI on WAS anaerobic digestion and may be technically useful for enhancing WAS anaerobic digestion and for energy recovery.

\section{Materials and methods}

\subsection{The experimental sludge and NZVI particle preparation}

Anaerobic digestion sludge (ADS) and WAS were used in the present study. The experimental ADS was taken from an anaerobic digester in a municipal WWTP in Shanghai, China; the experimental WAS was taken from the recycling sludge of a secondary sedimentation tank at the same WWTP. WAS was first settled for $8 \mathrm{~h}$ and filtered through mesh $(1.0 \mathrm{~mm})$, and then stored at $4{ }^{\circ} \mathrm{C}$ before use. The properties of the experimental WAS are listed in Table 1 . The NZVI synthesis method was shown in ESI, Text S1. $\uparrow$ The reduced iron powder (ZVI, 100 mesh) was purchased from Aladdin (Shanghai, China; product ID I116359).

\subsection{Experimental approach}

2.2.1. Effect of NZVI on hydrolysis-acidification using WAS. The effects of NZVI on hydrolysis-acidification were evaluated by microbiological arrays using WAS. The experiment was performed in $500 \mathrm{~mL}$ anaerobic bottles in mesophilic conditions $\left(35^{\circ} \mathrm{C}\right)$. Each bottle was fed with $400 \mathrm{~mL}$ WAS and a certain dosage of NZVI (final NZVI 0.0, 0.1, 0.6, 1.0, 4.0 or $10.0 \mathrm{~g} \mathrm{~L}^{-1}$ ) or ZVI ( 4.0 or $10.0 \mathrm{~g} \mathrm{~L}^{-1}$ ). Meanwhile, $50 \mathrm{mM}$ sodium 2-bromoethanesulfonate, a methanogenesis inhibitor, was
Table 1 Key parameters of the experimental waste activated sludge

\begin{tabular}{|c|c|c|}
\hline Parameter & $\begin{array}{l}\text { Value } \\
\text { (mean value } \pm \text { standard deviation) }\end{array}$ & Unit \\
\hline SS & $18.582 \pm 0.225$ & $\mathrm{~g} \mathrm{~L}^{-1}$ \\
\hline VSS & $13.056 \pm 0.161$ & $\mathrm{~g} \mathrm{~L}^{-1}$ \\
\hline $\mathrm{pH}$ & $7.64 \pm 0.11$ & - \\
\hline VFAs & $44.3424 \pm 8.871574$ & mg COD per $\mathrm{L}$ \\
\hline SCOD & $178.6 \pm 10.6$ & $\mathrm{mg} \mathrm{L}^{-1}$ \\
\hline TCOD & $18924.2 \pm 281.7$ & $\mathrm{mg} \mathrm{L}^{-1}$ \\
\hline Liquid-protein & $2.727 \pm 0.642(0.143 \pm 0.034)$ & $\begin{array}{l}\mathrm{mg} \mathrm{L}^{-1} \\
(\mathrm{mg} g \text { per } \mathrm{SS})\end{array}$ \\
\hline EPS-protein & $185.0 \pm 3.860(9.685 \pm 0.202)$ & $\begin{array}{l}\mathrm{mg} \mathrm{L}^{-1} \\
(\mathrm{mg} g \text { per SS})\end{array}$ \\
\hline $\begin{array}{l}\text { Liquid- } \\
\text { polysaccharides }\end{array}$ & $6.178 \pm 0.008(0.333 \pm 0.004)$ & $\begin{array}{l}\mathrm{mg} \mathrm{L}^{-1} \\
(\mathrm{mg} \text { g per SS) }\end{array}$ \\
\hline $\begin{array}{l}\text { EPS- } \\
\text { polysaccharides }\end{array}$ & $79.74 \pm 9.721(4.288 \pm 0.471)$ & $\begin{array}{l}\mathrm{mg} \mathrm{L}^{-1} \\
(\mathrm{mg} g \text { per } \mathrm{SS})\end{array}$ \\
\hline
\end{tabular}

added into each bottle to avoid the consumption of volatile fatty acids (VFAs). After purging with nitrogen (99.99\%) for $5 \mathrm{~min}$, the bottles were sealed and mixed at $160 \mathrm{rpm}$ for 4 days. To identify the possible mechanism of NZVI impacts on hydrolysis-acidification, the concentration of proteins and polysaccharides in both the extracellular polymeric substance (EPS) matrix and liquid, and the proportion of living bacteria (live/dead), were measured every $24 \mathrm{~h}$. VFAs were measured to evaluate the hydrolysis-acidification efficiency. All experiments were conducted in triplicate.

2.2.2. Effect of NZVI on the whole anaerobic digestion using ADS. In the monophase anaerobic digestion, as hydrolysis and methanogenesis processes simultaneously occur, it is hard to identify the phase (hydrolysis or methanogenesis) that has been greatly impacted by NZVI. Therefore, in this test, ADS was used as the experimental sludge, and ethanol was added as the substrate for methanogenesis. Thus, interference between hydrolysis-acidification and methanogenesis could be avoided, and only methanogenesis was studied. The experiment was conducted in $500 \mathrm{~mL}$ anaerobic bottles in mesophilic conditions $\left(35^{\circ} \mathrm{C}\right)$. Each bottle was fed with $300 \mathrm{~mL}$ ADS and $1 \mathrm{~mL}$ ethanol. $\mathrm{N}_{2}$ was introduced to the bottles to purge air, allowing an oxidation-reduction potential (ORP) $<-300 \mathrm{mV}$, then the bottles were sealed with sealing film. The final NZVI concentrations were $0.0,0.6,1.0,4.0$ and $10.0 \mathrm{~g} \mathrm{~L}^{-1}$, respectively, and ZVI concentrations were 4.0 and $10.0 \mathrm{~g} \mathrm{~L}^{-1}$. The test was undertaken for 31 days to ensure complete anaerobic digestion. $\mathrm{CH}_{4}$ and $\mathrm{H}_{2}$ production volume were measured on days $0,1,4$, $5,6,9,12,15,22,25$ and 31. At the end of the experiment (31 d), the sludge samples were collected for analysis of microbial community structure. All experiments were conducted in triplicate.

\subsection{Analytical methods}

2.3.1. Chemical and gas analysis. The mixed liquid suspended solid samples of WAS were collected at the designated times for analysis of total suspended solids (SS), volatile 
suspended solids (VSS), and live/dead bacteria. First, samples $(6.0 \mathrm{~mL})$ were filtered through $0.45 \mu \mathrm{m}$ membranes after centrifugation for $5 \mathrm{~min}$ at $63.78 \times g$ to obtain liquid and sludge samples. Filtered liquid was used for analysis of soluble chemical oxygen demand (SCOD), soluble protein, soluble polysaccharides and VFAs. The sediment was resuspended to the initial volume for EPS extraction through a heat extraction method, ${ }^{17}$ and the concentration of proteins and polysaccharides in the EPS matrix was measured. The gas produced in the tests were collected for $\mathrm{CH}_{4}$ and $\mathrm{H}_{2}$ concentration $\left(\mathrm{PCH}_{4}\right.$ and $\left.\mathrm{PH}_{2}\right)$ analysis. The test methods were shown in ESI, Text S2. $\dagger$

2.3.2. Model-based analysis. The key parameters used to determine degradability of WAS during anaerobic digestion are degradation extent $\left(f_{\mathrm{d}}\right)$ and the apparent first order hydrolysis rate constant $(k) . f_{\mathrm{d}}$ represents the fraction of the substrate that may be converted to methane, and $k$ is used to estimate the velocity of sludge conversion. ${ }^{18} f_{\mathrm{d}}$ is calculated by eqn (1).

$$
f_{\mathrm{d}}=B_{0}-B(t)
$$

where $B_{0}\left(\mathrm{~mL} \mathrm{CH}_{4}\right.$ per $\mathrm{g}$ VSS) is the biochemical methane potential (BMP), representing the final methane production, and $B(t)$ (mL $\mathrm{CH}_{4}$ per $\mathrm{g}$ VSS) is the cumulative methane production at time $t(\mathrm{~d})$.

In this study, $B_{0}$ and $k$ were calculated to evaluate the influence of NZVI on the whole anaerobic digestion process. The estimations were made by fitting methane production data to a first order kinetic model using Aquasim 2.1 with an objective function of residual sum of squares. ${ }^{19}$ A single substrate type model was used in this study (eqn (2)) ${ }^{20}$

$$
B(t)=B_{0}\left(1-\mathrm{e}^{-k t}\right)
$$

SCOD and VSS reduction were measured and the method was introduced in details in ESI, Text S3. $\dagger$

2.3.3. Microbial community structure. During the anaerobic digestion, two types of functional microorganisms including acidogenic bacteria and methanogens were evaluated by Illumina high-throughput sequencing technology. Sludge samples were collected from each bottle at the end of the tests, i.e., at day 4 and day 31 respectively for the hydrolysis-acidification test and for the whole anaerobic digestion test, for analysis of the relative abundance of acidogenic bacteria and methanogens. Detailed information on DNA extraction, PCR amplification and 16S rRNA gene based Illumina sequencing and data analysis are presented in ESI, Text S4.†

\section{Results}

3.1. Solubilization, reduction and bacterial live/dead ratio of WAS during hydrolysis-acidification at different NZVI/ZVI dosages

As shown in Fig. 1a, the solubilization of the WAS continuously increased, from $69.8 \%$ to $106.7 \%$, as NZVI addition increased from 0.1 to $10.0 \mathrm{~g} \mathrm{~L}^{-1}$. At $10.0 \mathrm{~g} \mathrm{~L}^{-1} \mathrm{NZVI}$ addition, the solubility of the WAS was $201.5 \%$ of the level in the control. In contrast,

addition of 4 or $10 \mathrm{~g} \mathrm{~L}^{-1} \mathrm{ZVI}$ had little impact on the solubility of the WAS. The WAS degradation rate improved with increasing NZVI additions from 0.0 to $10.0 \mathrm{~g} \mathrm{~L}^{-1}$, and VSS reduction reached a maximum value of $46.2 \%$ at $10.0 \mathrm{~g} \mathrm{~L}^{-1} \mathrm{NZVI}$, being $91.8 \%$ higher than that in the control. When 4.0 or $10.0 \mathrm{~g} \mathrm{~L}^{-1}$ ZVI were added, the sludge reduction was greater than that in the control, but much less than that with 4.0 or $10.0 \mathrm{~g} \mathrm{~L}^{-1} \mathrm{NZVI}$ addition.

The live/dead ratio in the WAS sharply decreased after NZVI addition (Fig. 1a). In particular, when $10.0 \mathrm{~g} \mathrm{~L}^{-1}$ NZVI were added, the live/dead ratio of the experimental WAS was only

(a)
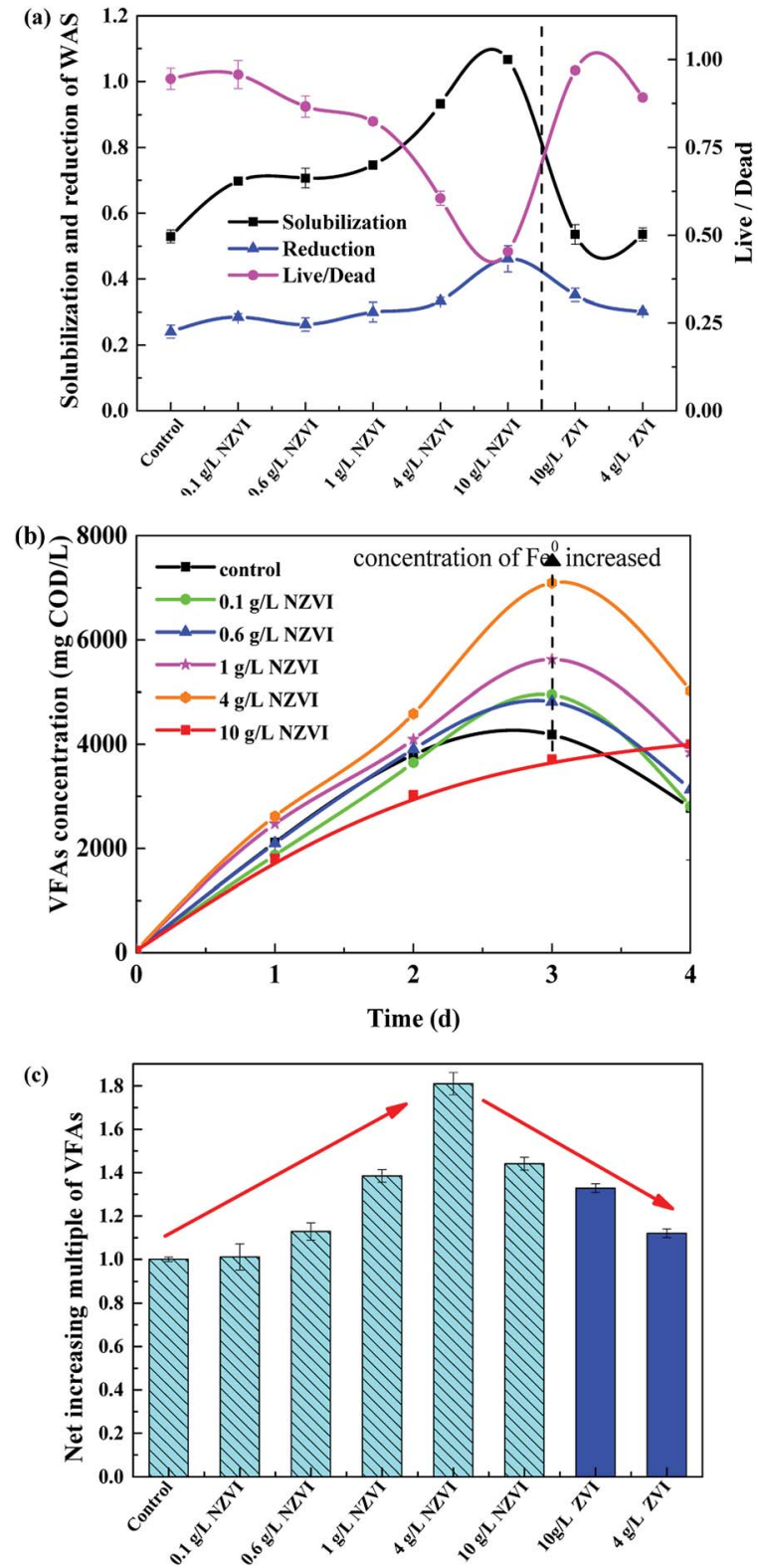

Fig. 1 (a) Solubilization, reduction and live/dead ratio in WAS on the $4^{\text {th }}$ day of hydrolysis-acidification; (b) volatile fatty acid (VFA) production during hydrolysis-acidification with different nano-zero valent iron (NZVI) additions; (c) the net effect on VFA levels on the $4^{\text {th }}$ day of hydrolysis-acidification with different NZVI (or ZVI) additions, with the control defined as 1.0 . 
0.45 , approximately $53.0 \%$ lower than that in the control, indicating significant death of biomass when exposed to $10.0 \mathrm{~g}$ $\mathrm{L}^{-1}$ NZVI. However, ZVI additions of 4 and $10 \mathrm{~g} \mathrm{~L}^{-1}$ had little impact on the live/dead ratio. It seems that NZVI could accelerate hydrolysis and improve biodegradability by cell membrane disruption. ${ }^{8}$

\subsection{VFA production during hydrolysis-acidification at different NZVI/ZVI dosages}

The acidification efficiency during a 4 day hydrolysis-acidification test at different NZVI/ZVI additions was assessed by evaluating VFA production characteristics, including accumulation (Fig. 1b) and composition (Fig. 2).

3.2.1. VFA production. Among all the experimental conditions, VFA production reached its maximum at $4.0 \mathrm{~g} \mathrm{~L}^{-1} \mathrm{NZVI}$, being $69.6 \%$ higher than that without NZVI addition (the control); the lowest VFA production occurred at $10 \mathrm{~g} \mathrm{~L}^{-1} \mathrm{NZVI}$ addition (Fig. 1b). VFA variation trends were similar at NZVI additions of $0.1,0.6,1.0$ and $4.0 \mathrm{~g} \mathrm{~L}^{-1}$ - they increased to the maximum on day 3 and decreased on day 4 (Fig. 1b). Specifically, the VFA concentrations at day 3 increased from 4948.5 to $7093.7 \mathrm{mg}$ COD per L with NZVI addition from 0.1 to $4.0 \mathrm{~g} \mathrm{~L}^{-1}$, and were all greater than the concentration in the absence of
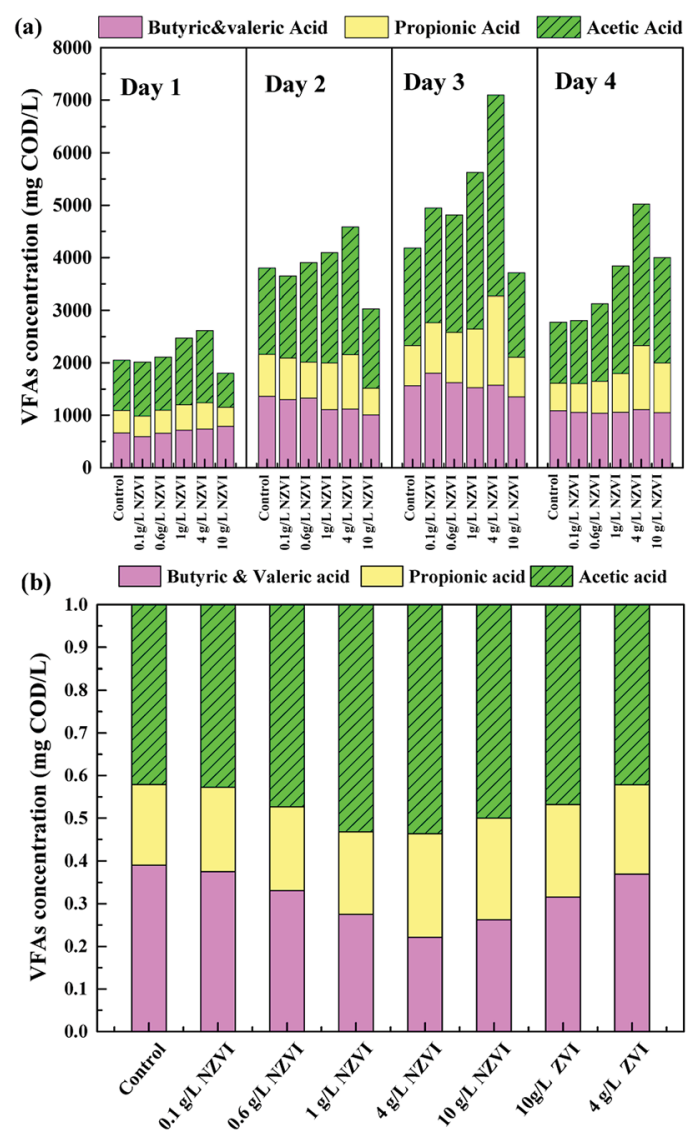

Fig. 2 Variations in VFA compositions during hydrolysis-acidification with different NZVI (or ZVI) additions. (a) Variations in the VFA composition during 4 days of fermentation at various NZVI dosages; (b) the VFA compositions on day 4 of hydrolysis-acidification at various NZVI (or ZVI) dosages.
NZVI. Similar results were reported by Luo et al., ${ }^{13}$ who added different dosages of NZVI $\left(0.5-5.0 \mathrm{~g} \mathrm{~L}^{-1}\right)$ into six WAS anaerobic fermentation reactors $(40 \mathrm{mM}$ of 2-bromoethanesulfonate was also added as methanogenic inhibitor), and found that VFA production was improved greatly as NZVI dosage increased from 0.5 to $5.0 \mathrm{~g} \mathrm{~L}^{-1}$, with the maximum yield (nearly six times higher than that in the control) occurring at $5.0 \mathrm{~g} \mathrm{~L}^{-1} \mathrm{NZVI}$ addition on day 4. It should be noted that, in the present study, when the NZVI addition was $10.0 \mathrm{~g} \mathrm{~L}^{-1}$, the VFA production and variation trend differed greatly from other addition conditions; the VFA concentration at $10.0 \mathrm{~g} \mathrm{~L}^{-1} \mathrm{NZVI}$ addition continued to increase throughout the experiment, reaching $4000 \mathrm{mg}$ COD per L on day 4 , but it was lower than that in the control on days 1-3 (Fig. 1b).

3.2.2. VFA composition. Acetate is the preferred carbon source in anaerobic digestion because only acetate among VFAs, together with formic acid, methanol, methylamine and hydrogen, can be directly used as a substrate for methane production. ${ }^{21}$ Therefore, the VFA composition variations were examined in the 4 day hydrolysis-acidification test, paying special attention to acetic acid (Fig. 2).

Acetic acid was the dominant VFA product during the hydrolysis-acidification process, and its concentration increased with increasing NZVI addition from 0.1 to $4.0 \mathrm{~g} \mathrm{~L}^{-1}$, with nearly all values greater than those in the control (Fig. 2a). On day 3 , the acetic acid concentrations peaked at 2182, 2236, 2981 and $3822 \mathrm{mg}$ COD per L respectively with $0.1,0.6,1.0$ and $4.0 \mathrm{~g} \mathrm{~L}^{-1} \mathrm{NZVI}$ addition. In contrast, $10.0 \mathrm{~g} \mathrm{~L}^{-1} \mathrm{NZVI}$ addition resulted in a proportion of acetic acid remarkably lower than that in the control during the initial 3 days of the experiment, but the level increased to $2000.0 \mathrm{mg}$ COD per L on day 4 (Fig. 2a). The percentages of propionic acid, butyric acid and valeric acid changed slightly with NZVI addition (Fig. 2a). Previous studies have also demonstrated the positive influence of NZVI on acetate production. For example, when NZVI was added to the WAS anaerobic digestion systems, Yang et al. ${ }^{16}$ found addition of $1.68 \mathrm{~g} \mathrm{~L}^{-1} \mathrm{NZVI}$ increased acetic acid dramatically on day 3; Yu et al. ${ }^{37}$ reported that the proportion of acetic acid was increased during a 3 day fermentation. However, the reason for this increment of acetate proportion on NZVI addition could not be determined in these studies.

As Fig. 2b shows, at the end of the test (day 4), the proportion of acetic acid increased to its maximum value of $53.7 \%$ at $4 \mathrm{~g}$ $\mathrm{L}^{-1}$ NZVI dosage, being approximately 1.3-times that in the control, and then decreased at $10.0 \mathrm{~g} \mathrm{~L}^{-1}$ dosage. On ZVI addition, acetic acid accounted for $46.8 \%$ and $42.2 \%$ of the total VFAs, respectively, when 10.0 and $4.0 \mathrm{~g} \mathrm{~L}^{-1} \mathrm{ZVI}$ were fed, being $12.8 \%$ and $21.4 \%$ lower, respectively, than that on $4.0 \mathrm{~g} \mathrm{~L}^{-1}$ NZVI addition (Fig. 2b). As enhanced acetate production would be thermodynamically favorable for methanogenesis, the improvement of VFA composition (i.e., high acetate acid percentage) by NZVI addition in this study could be beneficial for subsequent methanogenesis.

\subsection{Protein and polysaccharides in EPS and liquid during hydrolysis-acidification at different NZVI/ZVI dosages}

Protein and polysaccharides constitute the main organic matter in WAS and are important substrates for hydrolysis. ${ }^{13}$ As Fig. 3a 

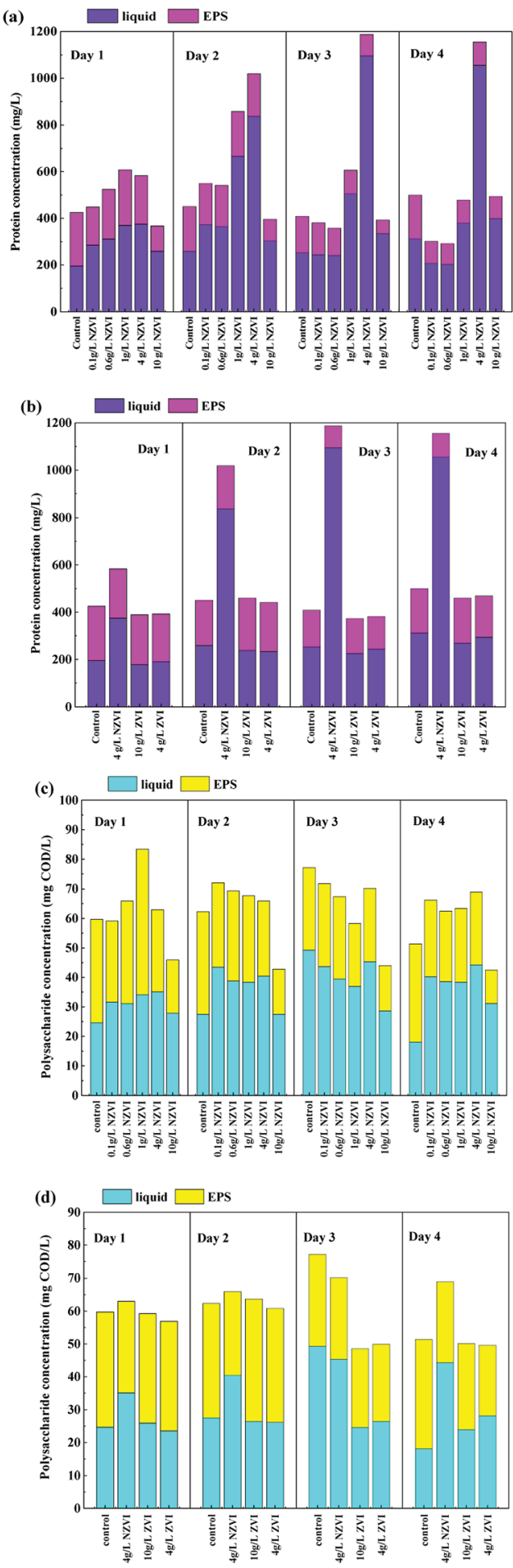

Fig. 3 Variations in protein and polysaccharide levels in the liquid and extracellular polymeric substances (EPS) during hydrolysis-acidification with different NZVI (or ZVI) additions. (a) Soluble protein and EPSprotein at various NZVI dosages; (b) soluble protein and EPS-protein at various NZVI (or ZVI) dosages; (c) soluble polysaccharide and EPSpolysaccharide at various NZVI dosages; (d) soluble polysaccharide and EPS-polysaccharide at various NZVI (or ZVI) dosages.

shows, the concentration of extracellular protein, both in the liquid and EPS, varied as NZVI dosage increasing from 0.0 to $10.0 \mathrm{~g} \mathrm{~L}^{-1}$, and the maximum value of $1187.5 \mathrm{mg} \mathrm{L}^{-1}$ occurred
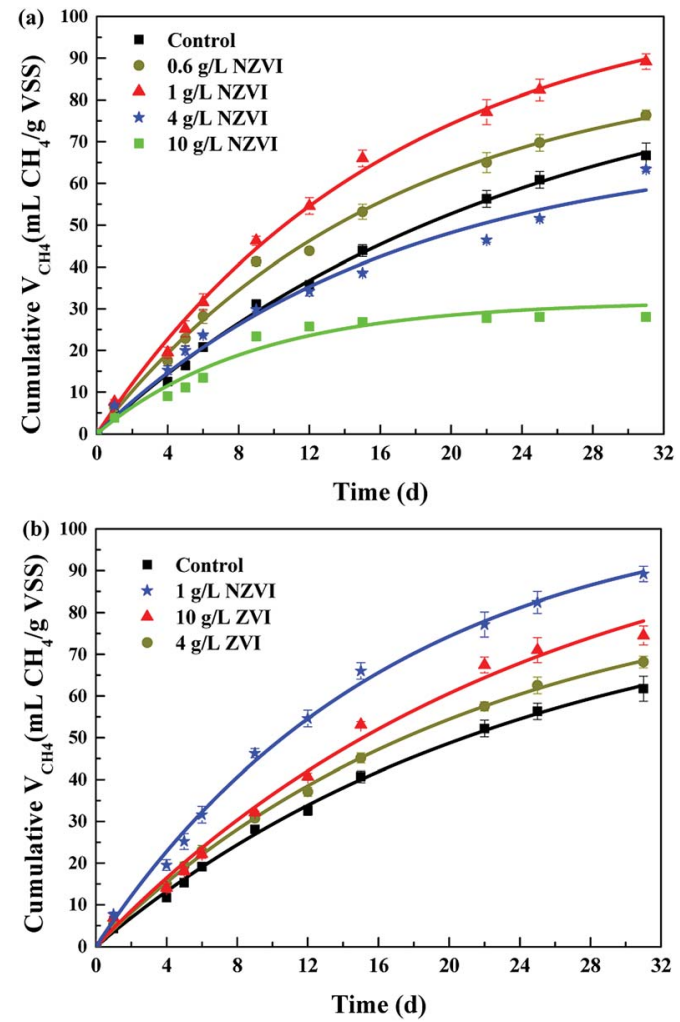

Fig. 4 Cumulative $\mathrm{CH}_{4}$ production during 31 day anaerobic digestion with different NZVI and ZVI additions. (a) The cumulative $\mathrm{CH}_{4}$ production at different NZVI additions; (b) The cumulative $\mathrm{CH}_{4}$ production at different $\mathrm{ZVI}$ additions.

at $4 \mathrm{~g} \mathrm{~L}^{-1}$ NZVI addition on day 3. Considering that the live/ Dead ratio of WAS (Section 3.1) was also decreased after NZVI addition (Fig. 1a), it was postulated that cell membranes had been ruptured, leading to the release of intracellular protein. ${ }^{22}$ This finding is in accordance with the production of VFAs, which increased with increasing NZVI addition from 0.1 to $4.0 \mathrm{~g}$ $\mathrm{L}^{-1}$ (Fig. 1b). It seems that NZVI could effectively accelerate the hydrolysis-acidification of biomass through disruption of cell membranes.

In contrast, ZVI addition did not affect the total extracellular protein content or the amount of protein in the EPS (Fig. 3b), suggesting that ZVI could not contribute to the disruption of cell walls or the degradation of EPS. Neither NZVI nor ZVI addition had an obvious influence on the total extracellular polysaccharide and EPS-polysaccharide contents (Fig. 3c and d), possibly because polysaccharides were efficiently degraded and absorbed by cells.

\section{4. $\mathrm{CH}_{4}$ and $\mathrm{H}_{2}$ production during anaerobic digestion at different NZVI/ZVI dosages}

The cumulative $\mathrm{CH}_{4}$ production at different NZVI and ZVI dosages was examined during the 31 day anaerobic digestion process test (Fig. 4) to elucidate the effects of NZVI on the anaerobic digestion process.

Various additions of NZVI had diverse effects on $\mathrm{CH}_{4}$ production (Fig. 4a). Sludge treated with $1 \mathrm{~g} \mathrm{~L}^{-1}$ NZVI produced 

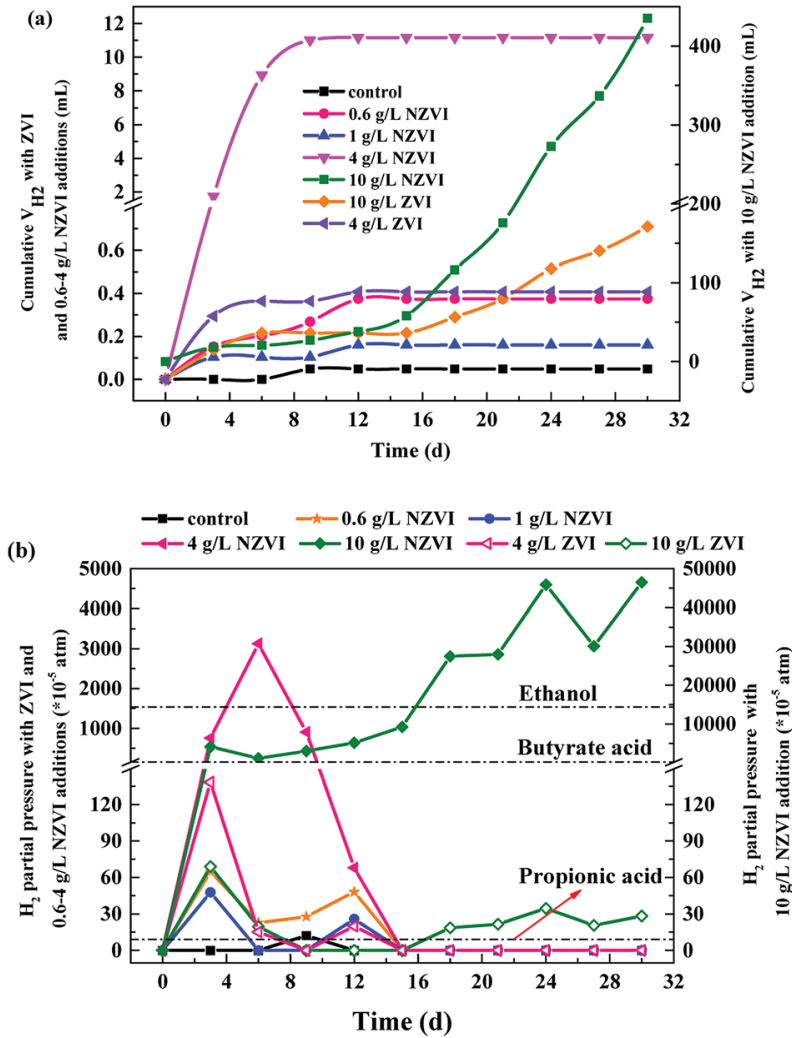

Fig. 5 (a) Cumulative $\mathrm{H}_{2}$ production during 31 day anaerobic digestion with different NZVI and ZVI additions; (b) cumulative $\mathrm{H}_{2}$ partial pressure during anaerobic digestion (31 d) with different NZVI (or ZVI) additions.

the highest methane amount, final production $89.2 \mathrm{~mL} \mathrm{CH}_{4}$ per $\mathrm{g}$ VSS, over 1.3 times that in the control. The lowest $\mathrm{CH}_{4}$ production, $28.1 \mathrm{~mL} \mathrm{CH}_{4}$ per $\mathrm{g}$ VSS, occurred at $10.0 \mathrm{~g} \mathrm{~L}^{-1}$ NZVI dosage, being $57.9 \%$ less than that in the control. Addition of 0.6 or $1 \mathrm{~g} \mathrm{~L}^{-1} \mathrm{NZVI}$ significantly promoted $\mathrm{CH}_{4}$ production, while 4.0 or $10.0 \mathrm{~g} \mathrm{~L}^{-1}$ NZVI substantially inhibited $\mathrm{CH}_{4}$ production (Fig. 4a). Such different effects of NZVI on $\mathrm{CH}_{4}$ production were also reported in previous studies. Carpenter et al..$^{33}$ reported that $1 \mathrm{~g} \mathrm{~L}^{-1} \mathrm{NZVI}$ and $1.25 \mathrm{~g} \mathrm{~L} \mathrm{~L}^{-1}$ NZVI dramatically stimulated methanogenesis compared with controls [a 3.7-fold (on day 21) and 10.7\% increase in methane production, respectively]. However, adding NZVI at a high dosage could inhibit methanogenesis, ${ }^{16,23}$ e.g., $69.0 \%$ reduction of methane production was observed on addition of $1.68 \mathrm{~g} \mathrm{~L}^{-1} \mathrm{NZVI}$ to anaerobic sludge. ${ }^{16}$ Addition of 4 and $10 \mathrm{~g} \mathrm{~L}^{-1}$ ZVI increased $\mathrm{CH}_{4}$ production by $10.4 \%$ and $20.6 \%$ respectively, but the promoting effects were not as remarkable as that of $1.0 \mathrm{~g}$ $\mathrm{L}^{-1}$ NZVI (Fig. 4b).

As to $\mathrm{H}_{2}$ production, both NZVI and ZVI, at each dose, could promote $\mathrm{H}_{2}$ production (Fig. 5a). The final volume of $\mathrm{H}_{2}$ was only $0.05 \mathrm{~mL}$ in the control. NZVI addition at $1.0 \mathrm{~g} \mathrm{~L}^{-1}$ had the smallest promoting effect with the final volume of $\mathrm{H}_{2}$ being only $0.16 \mathrm{~mL}$. At $4.0 \mathrm{~g} \mathrm{~L}^{-1} \mathrm{NZVI}$ addition, the final $\mathrm{H}_{2}$ volume increased sharply to $11.2 \mathrm{~mL}, 68.5$ times greater than that on $1 \mathrm{~g}$ $\mathrm{L}^{-1}$ NZVI addition. It should be noted that when NZVI addition was $10 \mathrm{~g} \mathrm{~L}^{-1}$, the $\mathrm{H}_{2}$ production process was significantly increased after day 16 and reached $435.5 \mathrm{~mL}$ on day 31, being 38.0 times higher than that with $1.0 \mathrm{~g} \mathrm{~L}^{-1} \mathrm{NZVI}$ addition. The fast and substantial accumulation of $\mathrm{H}_{2}$ at 4 and $10 \mathrm{~g} \mathrm{~L}^{-1} \mathrm{NZVI}$ additions (Fig. 5a) explained the inhibition of methanogenesis and lower $\mathrm{CH}_{4}$ production at these two dosages (Fig. 4a).

\subsection{Microbial population distribution during anaerobic digestion at different NZVI/ZVI dosages}

Sludge samples were collected at the end of the hydrolysisacidification test (day 4) and the whole anaerobic digestion process (day 31) for microbial community structure analysis using 16S rRNA high-throughput sequencing. The variations in hydrolysis-acidification and methanogenic archaea are detailed in ESI, Text S5. $\dagger$ In summary, NZVI addition stimulated proliferation of microorganisms responsible for hydrolysis-acidification, thus enhancing the hydrolysis and acidification processes in WAS.

\section{Discussion}

\subsection{Mechanism of the impact of NZVI on hydrolysis- acidification of WAS}

4.1.1. Cell membrane disruption by NZVI enhanced hydrolysis of WAS. We postulate that cell membrane disruption induced by NZVI resulted in release of intracellular materials, contributing to the enhancement of hydrolysis-acidification during WAS anaerobic digestion (Fig. 1 and 3). Generally, the initial solubilization and hydrolysis of particulate organics to soluble substances is the rate-limiting step during WAS anaerobic digestion. ${ }^{15}$ Even in the digested sludge, there are large amounts of undecomposed microbial residues, among which proteins and cellulose accounted for $33.4 \%$ and $43.4 \%$ of the total organics respectively in a previous study. ${ }^{24}$ This is because microorganisms (encased within cell membranes), as the major source of anaerobic digestion, are difficult to disrupt, which slows down the release and usage rate of intracellular organic matter. ${ }^{25}$ Most importantly, the cell envelopes are characterized by a semi-rigid structure which could provide sufficient strength to protect the cell from osmotic lysis. ${ }^{8}$

NZVI is able to disrupt cell membranes. ${ }^{26}$ By adding NZVI, the initial solubilization and hydrolysis of particulate organics (in WAS) to soluble substances, which is the rate-limiting step of anaerobic digestion, can be accelerated. Indeed, exposing anaerobic sludge to $1.68 \mathrm{~g} \mathrm{~L}^{-1}$ NZVI led to a significant increase in SCOD in the mixed liquid slurry, which was an indication of cell disruption. ${ }^{\mathbf{1 6}}$ Also, when Escherichia coli were exposed to NZVI, cell membrane disruption and leakage of the intracellular contents were observed; it was explained that NZVI addition caused the inactivation or enhanced a biocidal effect. ${ }^{27}$ Iron is a strong reductant $\left(E_{\mathrm{Fe}^{2+} / \mathrm{Fe}^{0}}^{0}=-0.447 \mathrm{~V}\right)$, and the reactive surfaces of NZVI directly interact with bacterial cells, and give rise to reductive decomposition of functional groups in proteins and lipopolysaccharides of the outer membranes, thus causing the disruption of the membranes. ${ }^{26}$

In the present study, NZVI addition facilitated the release of intracellular organic material to the liquid phase (Fig. 3), and 
improved further WAS solubility and VSS reduction (Fig. 1a). As a result, hydrolysis was accelerated and biodegradability was improved by the increase in dissolved organic matter, and, ultimately, VFA production was facilitated (Fig. 1b). As shown in Fig. 1c, the normalized VFA production on day 4 was greater than the control with NZVI additions from 0.1 to $10.0 \mathrm{~g} \mathrm{~L}^{-1}$.

4.1.2. NZVI addition decreased the ORP and optimized the VFA composition of WAS hydrolysis-acidification. VFAs are important intermediate products during hydrolysis-acidification of WAS, and mainly include acetic acid, propionic acid, butyric acid and valeric acid. Acetic acid is the most favourable fermentation product, and propionic acid should ideally be avoided. ${ }^{28}$ The present study showed that NZVI addition could improve the VFA composition that the acetic acid portion was increased (Fig. 2). Previous studies demonstrated that the fermentation type is closely related to the ORP. Propionic acidtype fermentation usually occurs when the ORP is $>-278 \mathrm{mV}$, while butyric and acetic acid-type fermentation occur at lower ORP. ${ }^{29}$ NZVI, a strong reductant $\left(E_{\mathrm{h}}=-0.44 \mathrm{~V}\right)$, could rapidly decrease the ORP of the system,,$^{30}$ creating good conditions for butyric and acetic acid-type fermentation. Coincidentally, the initial ORP in the experimental bioreactor was $<-300 \mathrm{mV}$ in the present study. Additionally, $\mathrm{Fe}^{0}$, as an electron donor, could enhance degradation of propionic acid,,$^{31}$ and also improve activity of the key enzymes for acetic acid type fermentation. ${ }^{32}$ Therefore, NZVI addition could improve the VFA composition by increasing acetic acid production during the WAS acidification.

\subsection{The mechanism of NZVI effects on the complete anaerobic digestion process}

4.2.1. Different variations in biochemical methane potential and hydrolysis rate coefficient in response to different NZVI/ZVI dosages. As shown in Fig. 6, NZVI addition from 0.6 to $1.0 \mathrm{~g} \mathrm{~L}^{-1}$ led to an increase in $B_{0}$ from 89 to $106 \%$, with the maximum value occurring at $1 \mathrm{~g}$ NZVI per $\mathrm{L}$ and being more than $22.5 \%$ greater than that in the control. However, as the NZVI addition increased further (to 4 and $10 \mathrm{~g} \mathrm{~L}^{-1}$ ), the $B_{0}$ value

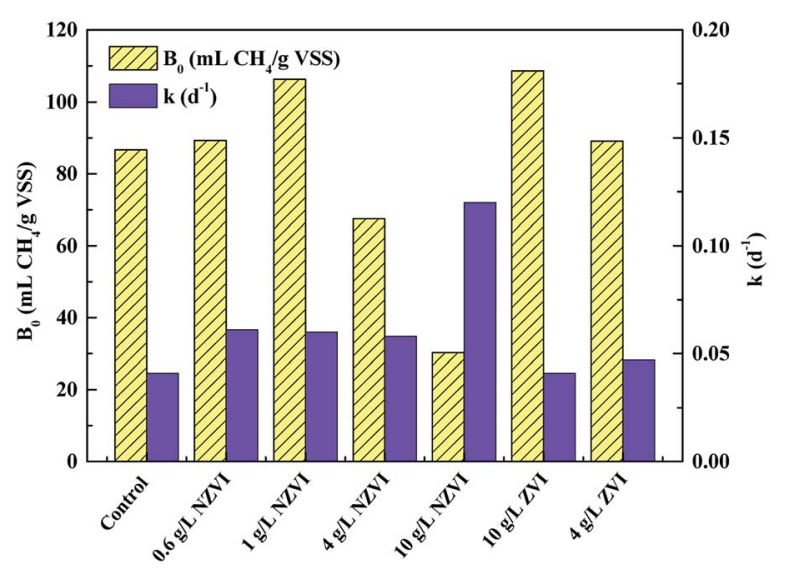

Fig. 6 Variations in biochemical methane potential $\left(B_{0}\right)$ and apparent first order hydrolysis rate constant ( $k$ ) of WAS with different NZVI (or ZVI) additions. sharply declined; at $10 \mathrm{~g} \mathrm{~L}^{-1}$ NZVI addition, $B_{0}$ was only $34.9 \%$ of that in the control. This observation was in accordance with the observed impact of NZVI on $\mathrm{CH}_{4}$ production (Fig. 4a) in that 0.6 or $1.0 \mathrm{~g} \mathrm{~L}^{-1}$ NZVI significantly promoted $\mathrm{CH}_{4}$ production, while 4.0 or $10.0 \mathrm{~g} \mathrm{~L}^{-1}$ NZVI substantially inhibited $\mathrm{CH}_{4}$ production.

Both improvement and inhibition effects of NZVI on $B_{0}$ (at appropriate and excess dosages respectively) have been observed in previous studies. For instance, addition of 0.3$1.25 \mathrm{~g} \mathrm{~L} \mathrm{~L}^{-1}$ NZVI led to a $10.7-60.5 \%$ increase in methane production. ${ }^{33}$ Similarly, Su et al. ${ }^{23}$ reported that NZVI dosages of 0.5 and $1.0 \mathrm{~g} \mathrm{~L}^{-1}$ increased methane production by $9.8 \%$ and $4.6 \%$ respectively; however, a NZVI dose of $2.0 \mathrm{~g} \mathrm{~L}^{-1}$ decreased the methane production by $8.8 \%$. Yang et al. ${ }^{14}$ demonstrated that NZVI at $\geq 0.056 \mathrm{~g} \mathrm{~L}^{-1}$ inhibited methane generation, and $1.68 \mathrm{~g} \mathrm{~L}^{-1}$ NZVI caused a reduction of methane production of $69.0 \%$. Clearly, the destruction of cell (including methanogens) integrity at high NZVI addition levels might contribute to inhibition of methanogenesis.

Unlike $B_{0}$, the hydrolysis rate coefficient $(k)$ continued to increase with increasing NZVI from 0.6 to $10.0 \mathrm{~g} \mathrm{~L}^{-1}$ (Fig. 6). This observation corresponded well with the finding that increasing NZVI addition from 0.6 to $10.0 \mathrm{~g} \mathrm{~L}^{-1}$ enhanced VFA production (Fig. 1b) due to cell disruption. Addition of NZVI from 0.6 to $4.0 \mathrm{~g} \mathrm{~L}^{-1}$ resulted in approximately the same value of $k$ (approximately $0.06 \mathrm{~d}^{-1}$ ). $k$ significantly increased, to $0.12 \mathrm{~d}^{-1}$, on addition of $10.0 \mathrm{~g} \mathrm{~L}^{-1}$ NZVI (Fig. 6). This finding confirmed that $10.0 \mathrm{~g} \mathrm{~L}^{-1}$ NZVI could rapidly cause damage to cell integrity, which corresponds to the live/dead ratio results showing that $10.0 \mathrm{~g} \mathrm{~L}^{-1}$ NZVI caused extensive death of microorganisms (Fig. 1a).

Addition of 4.0 and $10.0 \mathrm{~g} \mathrm{~L}^{-1} \mathrm{ZVI}$ enhanced $B_{0}$ but had little impact on $k$ (Fig. 6). It was suggested that ZVI enhanced methane production by improving the BMP of WAS, rather than its hydrolysis rate. This might be because ZVI could improve VFA composition. ${ }^{15}$ In addition, the $B_{0}$ values on 4.0 or $10.0 \mathrm{~g}$ $\mathrm{L}^{-1} \mathrm{ZVI}$ addition were similar to those that on 0.6 or $1.0 \mathrm{~g} \mathrm{~L}^{-1}$ NZVI addition, indicating that although ZVI could improve the BMP, its efficiency was lower than that of NZVI: to achieve the same enhancement effect, the required dosage of ZVI was almost 9 times greater than that of NZVI.

Taken together, our findings demonstrate that NZVI addition could accelerate the WAS hydrolysis rate, but does not definitely improve the BMP. ZVI addition could also improve hydrolysis-acidification and the $\mathrm{CH}_{4}$ yield, but its efficiency was relatively low when compared with NZVI, and it could not induce cell wall rupture.

4.2.2. Excessive accumulation of $\mathrm{H}_{2}$ induced by high NZVI addition inhibited $\mathbf{C H}_{4}$ production. $\mathrm{H}_{2}$ production was promoted by NZVI additions (Fig. 5). In this study, $\mathrm{H}_{2}$ can be produced both from NZVI (eqn (3)) ${ }^{\mathbf{1 2}}$ and by acidogenesis (eqn (4)). $\mathrm{Hu}$ et al. ${ }^{11}$ reported that $\mathrm{H}_{2}$ was easily produced during anaerobic digestion and increased with NZVI dosage from 0.5 to $5.0 \mathrm{~g}$, resulting in increasing promotion of $\mathrm{CH}_{4}$ production. Their findings confirmed that $\mathrm{H}_{2}$ generated from anaerobic NZVI oxidation could promote methanogenesis. However, excessive $\mathrm{H}_{2}$ accumulation inhibited methanogenesis, and this 
phenomenon tends to occur particularly following high NZVI addition, because a high concentration of NZVI with large specific surface area is highly reactive and could release $\mathrm{H}_{2}$ within a short time, which would cause a significant $\mathrm{H}_{2}$ shock to the anaerobic digestion system. ${ }^{34}$

$$
\begin{gathered}
\mathrm{Fe}^{0}+2 \mathrm{H}_{2} \mathrm{O} \rightarrow \mathrm{Fe}^{2+}+\mathrm{H}_{2}+2 \mathrm{OH}^{-} \\
\mathrm{CH}_{3} \mathrm{CH}_{2} \mathrm{COO}^{-}+3 \mathrm{H}_{2} \mathrm{O} \rightarrow \mathrm{CH}_{3} \mathrm{COO}^{-}+\mathrm{HCO}_{3}{ }^{-}+\mathrm{H}^{+}+3 \mathrm{H}_{2}
\end{gathered}
$$

The limiting $\mathrm{H}_{2}$ pressures for production of methane from acetic acid, propionic acid and butyric acid are $0.144,9 \times 10^{-5}$ and $2 \times 10^{-3}$ atm respectively. In this test, at 0.6 and $1.0 \mathrm{~g} \mathrm{~L}^{-1}$ NZVI, the partial pressure of $\mathrm{H}_{2}$ reached its maximum on day 3 and declined sharply on day 6 (Fig. 5b). On day 15, it decreased to $0 \mathrm{~atm}$, and there was no $\mathrm{H}_{2}$ accumulation at the end of the test (day 31). However, after 4 or $10 \mathrm{~g} \mathrm{~L}^{-1}$ NZVI were added, the $\mathrm{H}_{2}$ partial pressure was higher than the limiting value for the VFAs for a long time. In particular, at $10 \mathrm{~g} \mathrm{~L}^{-1}$ NZVI the $\mathrm{H}_{2}$ partial pressure rose to 0.465 atm on day 31 , indicating that the anaerobic digestion system lost self-adjustment capacity and had been destroyed. ZVI addition also increased $\mathrm{H}_{2}$ partial pressure, but the effect was not so obvious (Fig. 5b). From the microbial point of view, hydrogenotrophic methanogens and bacteria such as homoacetogens would compete for available $\mathrm{H}_{2}$ in anoxic environments, and the capacity of the methanogens to compete with homoacetogens for $\mathrm{H}_{2}$ decreases with increasing $\mathrm{H}_{2}$ concentration. ${ }^{35}$ Therefore, an appropriate increase of $\mathrm{H}_{2}$ production contributes to the enhancement of methanogenesis because $\mathrm{H}_{2}$ can be used by hydrogen-trophic methanogens, but excess $\mathrm{H}_{2}$ accumulation inhibits methanogenesis, leading to decreased $\mathrm{CH}_{4}$ production (Fig. 4a).

Additionally, our results illustrate that adding 0.1 to $4.0 \mathrm{~g} \mathrm{~L}^{-1}$ NZVI promoted VFA production (Fig. 1b), and $\mathrm{CH}_{4}$ production increased with increasing NZVI dosage only from 0.6 to $1.0 \mathrm{~g} \mathrm{~L}^{-1}$ (Fig. 4a), indicating that the optimal dosage of NZVI enhancing acidification and methanogenesis were not matched in this one-phase anaerobic digestion system, although generally the more fatty acids formed, the more $\mathrm{CH}_{4}$ is produced. ${ }^{16}$ It seems that NZVI addition had an independent influence on methanogenesis, which might be due to the inhibition of methanogenesis at high partial pressure of $\mathrm{H}_{2}$ at the higher NZVI dosages.

\subsection{The correlation of relative abundance of bacteria involved in WAS hydrolysis-acidification and methanogens with different NZVI dosages}

Redundancy analysis (RDA) of the bacterial community structure at the phylum level following different NZVI and ZVI additions is shown in Fig. 7a. Functional bacteria involved in WAS hydrolysis-acidification were positively correlated with the NZVI concentration, while non-functional bacteria were negatively correlated (Fig. 7a), indicating that NZVI is beneficial to the growth of functional bacteria. Specifically, Bacteroidetes, associated with propionic fermentation-type microorganisms, ${ }^{36}$ were among the most abundant bacteria in the cultures, were negatively correlated with NZVI dosages (Fig. 7a), indicating that propionic acid-type fermentation was inhibited by NZVI addition. The relative abundance of Clostridia increased with NZVI addition (Table S1 $\dagger$ ); the main functional bacteria of butyric acid fermentation are affiliated to Clostridia, which mainly produce acetic and butyric acids when degrading organic matter. ${ }^{37}$ Accordingly, butyric acid fermentation was promoted by the action of NZVI (Fig. 2a), and the VFA composition was optimized.

In the anaerobic digestion of wastewater or WAS, the orders Methanobacteriales, Methanomicrobiales and Methanosarcinales contain the main methane-producing bacteria, ${ }^{38}$ among which only Methanosarcinales are aceticlastic methanogens. ${ }^{39}$ RDA analysis performed between methanogens at the genus level after different NZVI and ZVI additions showed that NZVI had much greater impacts on the microbial distribution than ZVI (Fig. 7b).

The relative abundances of the genera Methanobacterium, Methanospirillum and Methanolinea were positively correlated with the NZVI concentration (Fig. 7b), suggesting that NZVI addition was beneficial for these methanogens (Table S4 $\dagger$ ).
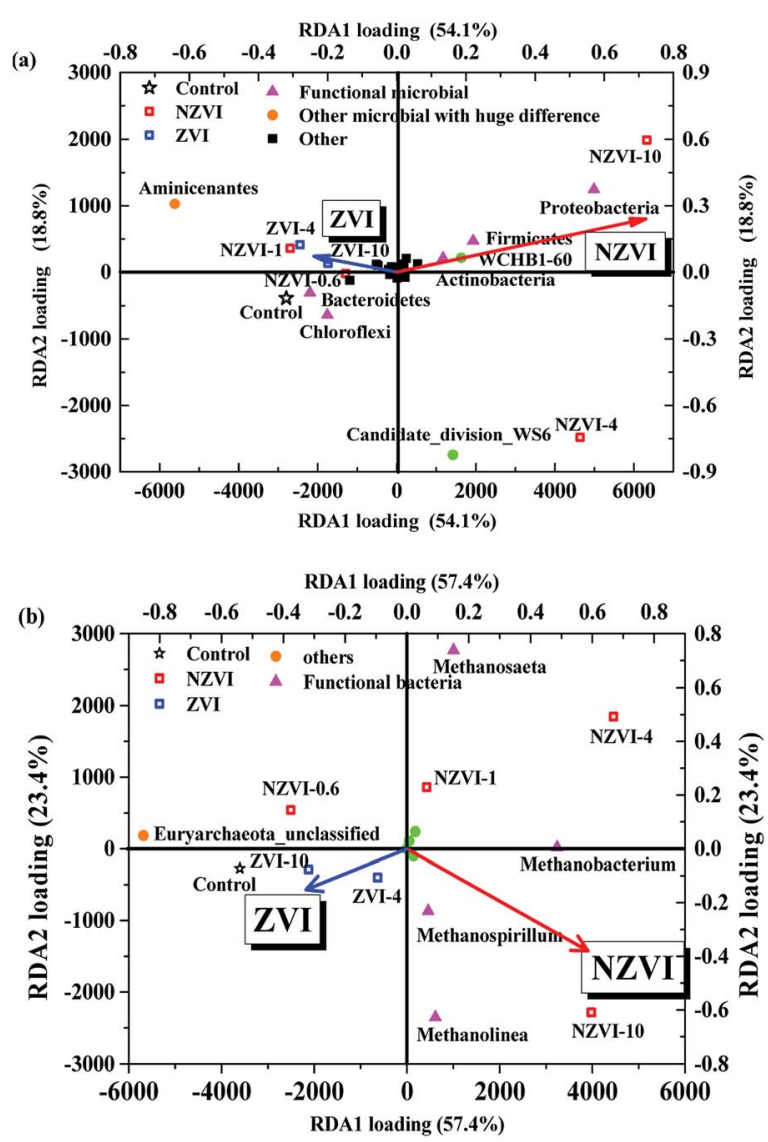

Fig. 7 (a) Redundancy analysis (RDA) of bacterial structure (at the phylum level) with different NZVI (or ZVI) additions; (b) RDA of methanogens (at the genus level) with different NZVI (or ZVI) additions. The red and blue arrows respectively show the impacts of NZVI and $Z \mathrm{VI}$ concentrations on the main components in the system. NZVI-0.6, $\mathrm{NZVI}-1, \mathrm{NZVI}-4$ and NZVI-10 represents respectively 0.6, 1.0, 4.0 and $10.0 \mathrm{~g} \mathrm{~L}^{-1} \mathrm{NZVI}$. ZVI-4 and ZVI-10 represents respectively 4.0 and $10.0 \mathrm{~g} \mathrm{~L}^{-1} \mathrm{ZVI}$. 
Although Methanosaeta increased with increasing NZVI addition, it was not the dominant genus, shown by the obtuse angle between the triangle representing Methanosaeta and the red arrow in Fig. 7b. Therefore, we postulate that NZVI addition was more beneficial to hydrogenotrophic methanogens than to aceticlastic methanogens. Indeed, $\mathrm{Hu}$ et al. ${ }^{9}$ also found that in an anaerobic system with $\mathrm{CO}_{2}$ as the sole carbon source, heterotrophic methanogens gradually decreased while hydrogenotrophic methanogens dominated as the NZVI concentration was increased, indicating that NZVI could promote the growth of hydrogenotrophic methanogens.

Anaerobic digestion is a promising technology to recover renewable resources and achieve "carbon neutral" or even "carbon positive" WWTPs. However, the relatively low efficiency of hydrolysis and methanogenesis limits its application, and most current pretreatments have low cost-efficiency. In this study, we showed that addition of NZVI at a proper dosage could effectively enhance anaerobic digestion of WAS. Therefore, it can serve as a highly efficient method for promoting anaerobic digestion and has a great potential to be applied in WWTPs for energy recovery.

\section{Conclusions}

NZVI addition from 0.1 to $4.0 \mathrm{~g} \mathrm{~L}^{-1}$ could effectively enhance hydrolysis-acidification through disruption of cell membranes. The optimal dosage of NZVI was $4.0 \mathrm{~g} \mathrm{~L}^{-1}$, at which VFA and acetic acid accumulation were greatly increased. Addition of 0.6 and $1.0 \mathrm{~g} \mathrm{~L}^{-1}$ NZVI could effectively promote $\mathrm{CH}_{4}$ production through disruption of cell membranes, and the optimal dosage of NZVI for cumulative methane volume was $1.0 \mathrm{~g} \mathrm{~L}^{-1}$. While NZVI addition at 4.0 and $10.0 \mathrm{~g} \mathrm{~L}^{-1}$ caused inhibition of methanogenesis due to substantial $\mathrm{H}_{2}$ accumulation. ZVI could also improve hydrolysis-acidification and the $\mathrm{CH}_{4}$ yield, but its efficiency was relatively low compared with NZVI.

\section{Conflicts of interest}

There are no conflicts to declare.

\section{Acknowledgements}

This work was supported by the National Natural Science Foundation of China (NSFC) (51778446 and 51522809). The Foundation of the State Key Laboratory of Pollution Control and Resource Reuse (Tongji University, China) (PCRRY 0400231010) is also acknowledged.

\section{References}

1 P. Jenicek, J. Bartacek, J. Kutil, J. Zabranska and M. Dohanyos, Water Sci. Technol., 2012, 66, 1277-1281.

2 C. Zamalloa, E. Vulsteke, J. Albrecht and W. Verstraete, Bioresour. Technol., 2011, 102, 1149-1158.

3 W. Wei, X. Zhou, D. Wang, J. Sun and Q. Wang, Water Res., 2017, 118, 12-19.
4 Y. Cao and A. Pawłowski, Renewable Sustainable Energy Rev., 2012, 16, 1657-1665.

5 M. Imbierowicz and A. Chacuk, Water Res., 2012, 46, 57475755.

6 J. Zhao, D. Wang, X. Li, Q. Yang, H. Chen, Y. Zhong and G. Zeng, Water Res., 2015, 78, 111-120.

7 Q. Xu, X. Li, R. Ding, D. Wang, Y. Liu, Q. Wang, J. Zhao, F. Chen, G. Zeng, Q. Yang and H. Li, Water Res., 2017, 124, 269-279.

8 J. A. Muller, Water Sci. Technol., 2001, 44, 121-128.

9 U. Kepp, I. Machenbach, N. Weisz and O. E. Solheim, Water Sci. Technol., 2000, 42, 89-96.

10 S. Gössling, Journal of Sustainable Tourism, 2009, 17, 17-37. 11 Y. Hu, X. Hao, D. Zhao and K. Fu, Chemosphere, 2015, 140, 34-39.

12 S. Karri, R. Sierra-Alvarez and J. A. Field, Biotechnol. Bioeng., 2005, 92, 810-819.

13 J. Luo, L. Feng, Y. Chen, X. Li, H. Chen, N. Xiao and D. Wang, J. Biotechnol., 2014, 187, 98-105.

14 L. Su, X. Shi, G. Guo, A. Zhao and Y. Zhao, J. Mater. Cycles Waste Manage., 2013, 15, 461-468.

15 Y. Feng, Y. Zhang, X. Quan and S. Chen, Water Res., 2014, 52, 242-250.

16 Y. Yang, J. Guo and Z. Hu, Water Res., 2013, 47, 6790-6800. 17 S.-f. Yang and X.-y. Li, Process Biochem., 2009, 44, 91-96.

18 P. D. Jensen, H. Ge and D. J. Batstone, Water Sci. Technol., 2011, 64, 880.

19 D. Batstone, S. Tait and D. Starrenburg, Biotechnol. Bioeng., 2009, 102, 1513-1520.

20 M. A. Latif, C. M. Mehta and D. J. Batstone, Water Res., 2015, 81, 288-293.

21 G. Zhen, X. Lu, Y.-Y. Li, Y. Liu and Y. Zhao, Chem. Eng. J., 2015, 263, 461-470.

22 J. Jimenez, F. Vedrenne, C. Denis, A. Mottet, S. Déléris, J.-P. Steyer and J. A. C. Rivero, Water Res., 2013, 47, 17511762.

23 L. Su, G. Zhen, L. Zhang, Y. Zhao, D. Niu and X. Chai, Environ. Sci.: Processes Impacts, 2015, 17, 2013-2021.

24 S. Inoue, S. Sawayama, T. Ogi and S. Y. Yokoyama, Biomass Bioenergy, 1996, 10, 37-40.

25 D. C. Devlin, S. R. Esteves, R. M. Dinsdale and A. J. Guwy, Bioresour. Technol., 2011, 102, 4076-4082.

26 J. Y. Kim, C. Lee, D. C. Love, D. L. Sedlak, J. Yoon and K. L. Nelson, Environ. Sci. Technol., 2011, 45, 6978-6984.

27 J. Y. Kim, H.-J. Park, C. Lee, K. L. Nelson, D. L. Sedlak and J. Yoon, Appl. Environ. Microbiol., 2010, 76, 7668-7670.

28 M. Tatara, T. Makiuchi, Y. Ueno, M. Goto and K. Sode, Bioresour. Technol., 2008, 99, 4786-4795.

29 N. Ren, H. Chua, S. Chan, Y. Tsang, Y. Wang and N. Sin, Bioresour. Technol., 2007, 98, 1774-1780.

30 R.-F. Yu, H.-W. Chen, W.-P. Cheng, Y.-J. Lin and C.-L. Huang, J. Taiwan Inst. Chem. Eng., 2014, 45, 947-954.

31 L. Daniels, N. Belay, B. S. Rajagopal and P. J. Weimer, Science, 1987, 237, 509-511.

32 A. F. Yakunin and P. C. Hallenbeck, Biochim. Biophys. Acta, Bioenerg., 1998, 1409, 39-49. 
33 A. W. Carpenter, S. N. Laughton and M. R. Wiesner, Environ. Eng. Sci., 2015, 32, 647-655.

34 Y.-X. Huang, J. Guo, C. Zhang and Z. Hu, Water Res., 2016, 88, 475-480.

35 O. R. Kotsyurbenko, M. V. Glagolev, A. N. Nozhevnikova and R. Conrad, FEMS Microbiol. Ecol., 2001, 38, 153-159.

36 H.-Q. Tan, T.-T. Li, C. Zhu, X.-Q. Zhang, M. Wu and X.-F. Zhu, Int. J. Syst. Evol. Microbiol., 2012, 62, 2613-2617.
37 B. Yu, X. Huang, D. Zhang, Z. Lou, H. Yuan and N. Zhu, RSC Adv., 2016, 6, 24236-24244.

38 D. Boone, R. Castenholz and G. Garrity, Bergey's manual of systematic bacteriology, Springer, New York, 2001, vol. 1.

39 S. Beckmann, T. Lueders, M. Krueger, F. von Netzer, B. Engelen and H. Cypionka, Appl. Environ. Microbiol., 2011, 77, 3749-3756. 